\title{
Upregulation of nucleostemin in colorectal cancer and its effects on cell malignancy [Retraction]
}

It was recently brought to our attention that a paper published in 2015 by Bin Wei, Qiaoying Huang, Xiaogang Zhong.

- Wei B, Huang Q, Zhong X. Upregulation of nucleostemin in colorectal cancer and its effects on cell malignancy. OncoTargets and Therapy. 2015;8:1805-1814.

Plagiarized significant portions of the text and several figures published in 2014:
- Seyed-Gogani N, Rahmati M, Zarghami N, et al. Nucleostemin Depletion Induces Post-G1 Arrest Apoptosis in Chronic Myelogenous Leukemia K562 Cells. Advanced Pharmaceutical Bulletin. 2014;4(1):55-60.

The editor and publishers take the view that this is completely unacceptable. This paper is retracted.
OncoTargets and Therapy

\section{Publish your work in this journal}

OncoTargets and Therapy is an international, peer-reviewed, open access journal focusing on the pathological basis of all cancers, potential targets for therapy and treatment protocols employed to improve the management of cancer patients. The journal also focuses on the impact of management programs and new therapeutic agents and protocols on

\section{Dovepress}

patient perspectives such as quality of life, adherence and satisfaction. The manuscript management system is completely online and includes a very quick and fair peer-review system, which is all easy to use. Visit http://www.dovepress.com/testimonials.php to read real quotes from published authors. 